Please do not remove this page

RMIT

UNIVERSITY

\title{
Organizational mimesis and the emergence of industry superannuation in Australia
}

Mees, Bernard

https://researchrepository.rmit.edu.au/esploro/outputs/9921860758001341/filesAndLinks?institution=61RMIT_INST\&index=null

Mees, B. (2017). Organizational mimesis and the emergence of industry superannuation in Australia. Journal of Management History, 23(3), 241-258. https://doi.org/10.1108/JMH-03-2017-0013

Document Version: Accepted Manuscript

Published Version: https://doi.org/10.1108/JMH-03-2017-0013

Repository homepage: https://researchrepository.rmit.edu.au

(C) Emerald Publishing Limited

Downloaded On 2023/04/26 18:09:43 +1000

Please do not remove this page 
Thank you for downloading this document from the RMIT Research Repository.

The RMIT Research Repository is an open access database showcasing the research outputs of RMIT University researchers.

RMIT Research Repository: http://researchbank.rmit.edu.au/

\section{Citation:}

Mees, B 2017, 'Organizational mimesis and the emergence of industry superannuation in Australia', Journal of Management History, vol. 23, no. 3, 2, pp. 241-258.

See this record in the RMIT Research Repository at:

http://researchbank.rmit.edu.au/view/rmit:43443

Version: Accepted Manuscript

\section{Copyright Statement:}

(c) Emerald Publishing Limited

Link to Published Version:

https://dx.doi.org/10.1108/JMH-03-2017-0013 


\title{
Organizational mimesis and the emergence of industry superannuation in Australia
}

\author{
Bernard Mees, RMIT University
}

\begin{abstract}
Purpose:

This paper analyses the emergence of organizational isomorphism in the industry superannuation sector in Australia. The largest not-for-profit private businesses in the country, the industry funds were created in the 1980s in light of a broader union campaign to extend occupational retirement savings provision to all employees in Australia.
\end{abstract}

\section{Design/methodology/approach}

The emergence of organizational isomorphism among the industry funds is assessed from the perspective of institutional theory. The study is based on interviews with key players in the establishment of the industry superannuation sector, original archival research as well as contemporary public commentaries and more recent historical assessments.

\section{Findings}

The tripartite framework of institutional isomorphism established by DiMaggio and Powell is unable to explain the emergence of the widespread organizational isomorphism found in industry superannuation. Employing the more recent notion of institutional logics allows a more satisfactory explanation for the convergence in models of retirement-savings provision in the industry superannuation sector.

\section{Originality/value}

Organizational isomorphism cannot be described simply in terms of a tripartite framework of professional normativity, state coercion and market-based mimesis. Alternatively governed organizations such as those created by trade unions may develop in a different manner than social enterprises founded by less powerful social actors. 


\section{Introduction}

Superannuation is the term used in Australia for what are internationally styled occupational or private pensions. And the largest private companies by value in Australia are industry superannuation funds, not-for-profit wealth management businesses that have transformed the finance sector since they were established in the 1980s. Today, the largest of the industry funds, AustralianSuper, has funds under management of over AUD 100 billion, making it comparable in size to the wealth management arms of the four main Australian commercial banks. Extremely successful social enterprises, the industry superannuation funds comprise the fastest growing and most successful sector in the Australian finance industry.

Industry superannuation funds are "alternative organizations" in the sense advocated by Hartmann (2014) in his recent critique of critical management studies. Hartman admonishes management researchers for being too concerned with the dominant model of listed corporations and not enough with alternatively governed business enterprises. The industry funds are legally established as trusts with corporate trustees owned by their union and employer association sponsors - they are not member-owned businesses, but rather "semi-mutual" or "hybrid" member-centred organizations in terms of the taxonomies of Birchall (2011). The industry funds have consistently outperformed their for-profit rivals, having increased their market share of funds under management by 200\% since the mid-1990s (Markey et al. 2014, Productivity Commission 2016, p. 212). Yet the outstanding success of the not-forprofit schemes is merely one aspect of the industry superannuation funds that makes them so remarkable.

One of the key features of the industry superannuation funds is that they are run in very similar manners and have separated their key managerial functions out in nearly identical ways. A form of organizational isomorphism developed in the 1980s that still characterizes the management and governance structures of the largest industry superannuation schemes presently. The management model used by funds such as AustralianSuper is different to that employed in public-sector or for-profit schemes and was originally developed at Building Unions Superannuation (now Construction and Building Unions Superannuation or Cbus), still one of the largest retirement-savings plans in Australia. This isomorphism occurred, however, in a different manner than that assumed in traditional explanations of organizational similarity.

\section{Background}

Organizational isomorphism is a notion most often associated with institutional theory, particularly the tripartite framework of organizational isomorphism elucidated by DiMaggio and Powell (1983). Institutional theory takes a neo-Weberian approach to investigating normativity and rule-formation among industry participants as they adjust to broader systemic constraints, from government regulation to professional cultures and prevailing industry norms. Institutional theory stresses the emergence of organisational isomorphism and the limits visited by institutions on various types of personal agency (Scott 1995). More recently, however, DiMaggio and Powell's focus on organizational isomorphism has been significantly superseded, particularly in 
business research, by a focus on differentiation (rather than sameness) and the notion of institutional logics (Friedland and Alford 1991). Indeed Lounsbury (2007) has used this understanding in his institutional study of the American mutual funds industry, seeing its main historical development in terms of two competing institutional logics: an older logic associated with the Boston trustee model and the more recent New York investment management approach to financial services provision.

Institutional theory was developed in sociology, not history, and its key precepts have rarely been subjected to close historical analysis. Sociologists have long been encouraged to use their "sociological imagination" in a historical or diachronic sense, with many key developments of sociological theory being founded on analyses of change over time (Mills 1959). Institutional theory is largely an American development, emerging from the structural-functionalist tradition of the 1940s and $50 \mathrm{~s}$, and it is based on the broader conceptual notion that the "historical patterns of material practices, assumptions, values, beliefs, and rules by which individuals produce and reproduce their material subsistence, organize time and space, and provide meaning to their social reality" are socially constructed and not necessarily "rational" in the Weberian sense (Thornton and Ocasio 1999:804). But DiMaggio and Powell's (1983) tripartite interpretative framework does not seem readily to explain what has occurred in industry superannuation in Australia (cf. the summary by Thornton et al. [2012] reproduced here as table 1).

The model of superannuation provision employed by the leading industry superannuation funds is that established at Building Unions Superannuation (BUS) in 1984. BUS began its first years of operation under considerable political pressure, being declaimed in 1985 by the conservative opposition leader as a "Chicago-style extortion racket" (Howard 1985). As the Australian Accountant noted that year, of the retirement-savings plans being developed by the union movement at the time, "The most notorious of these is the Building Unions' Superannuation (BUS) Scheme" (Simon 1985, p. 37). BUS is the most innovative, successful and controversial retirement-savings fund ever established in Australia. A multi-employer scheme with hundreds of participating employers, nothing quite like it had been seen before in retirement-savings provision either in Australia or internationally. The BUS model was adopted by the other large industry funds founded after its establishment in 1984 and has increasingly also influenced the development of public-sector superannuation schemes, many of which now operate according to a similar model. But the tripartite framework of institutional isomorphism delineated by DiMaggio and Powell does not explain the origins and broader uptake of the management model used in industry superannuation. Another form of interpretative analysis is required to understand the origins of the model used in the management of contemporary industry superannuation schemes in Australia.

\section{The BUS model}

Superannuation is largely a development of the nineteenth century and the term was originally used to distinguish retirement pensions awarded to employees who had "superannuated" due to old age from those traditionally awarded to military and naval personnel because of injury or after a reaching a set period of service. Superannuation arrangements were first developed for public-sector employees and were later adopted 
by colonial enterprises such as the British East India Company in order to attract and retain staff (Hannah 1986). The use of occupational pension schemes spread throughout the British Empire, with the oldest employer-funded retirement plan in Australia being developed in 1842 by the London-based Bank of Australasia (Mees and Brigden 2017:9). Self-funded superannuation schemes had also been available to members of unions such as the Amalgamated Society of Engineers since it was founded in 1851 and public-sector plans are first recorded in the United States in the 1850s. Canada's first formal employer-sponsored retirement scheme was established in 1874 as the Grand Trunk Railway of Canada Superannuation and Provident Fund Association, and the oldest corporate plan recorded in the United States, the American Express Company's pension scheme, dates from as late as 1875, well after the earliest private pension arrangements had emerged in other common law countries (Chandler 1910:67; Latimer 1932:20-23; Clark et al. 2003:4).

By the 1910s, retirement pensions had become of key interest to Australian public-sector unions. Most public-sector schemes had been established in colonial times, with their extension to state-run enterprises and employees of local municipalities typically being a much later development. In 1896, two-thirds of the members of the New South Wales Civil Service Superannuation Fund had been allowed to withdraw from the scandal-ridden arrangement which had been drastically underfinanced by the colonial government (SMH 1895, SMH 1897). In 1916, however, a new scheme was enacted after a seven-year campaign by the New South Wales Public Service and Public Schools Teachers Associations. A plan that offered unit-based pensions to retired workers after they had reached age 65, the New South Wales State Superannuation Scheme opened in 1919 and was seen by its proponents to represent the most advanced arrangement of its kind internationally at the time (Carmichael 1913, Shields 1913).

The year after the New South Wales superannuation bill had finally received royal assent, the Miners' Federation publicist Harry "Long Drill" Jones published a pamphlet demanding improvements in the employment conditions of coal and oil shale mine workers and the implementation of an industry-wide retirement scheme (Jones 1917). Pension arrangements became an increasing focus of industrial bargaining over the next decade and in 1938 mining unions won agreement for statebased industrial pension arrangements to be established right across the country (Ross 1987:332-33, Mees and Brigden 2017:20-23). More schemes were won by unions in the $1950 \mathrm{~s}$ and $60 \mathrm{~s}$, but by the end of the 1970 s superannuation coverage was still limited mostly to public-sector workers and the head-office staff of the larger privatesector employers. Only limited numbers of blue-collar workers and very few women had access to superannuation entitlements in Australia before the 1984 establishment of Building Unions Superannuation (Gunasekera and Powlay 1987).

BUS was formed as the outcome of an attempt to reduce industrial disputation in the building and construction industry (Weaven 2016, Mees and Brigden 2017:4647). A range of craft-based unions represented workers in building and construction at the time, with separate unions covering occupations such as plumbing, painting, carpentry, plastering and laboring. By the 1980s these unions had also come to be separated into separate "building" and "construction" groups by industrial relations commissions, largely in reflection of political orientation. The two largest building unions were the Building Workers' Industrial Union (BWIU) and the Australian Building Construction Employees' and Builders' Labourers' Federation (BLF). Pat 
Clancy, the leader of the BWIU, was also the president of the Socialist Party of Australia, a Leninist splinter from the Australian Communist Party (which had adopted Eurocommunism after the Soviet invasion of Czechoslovakia in 1968). The head of the BLF was Norm Gallagher, a senior figure in the earlier Maoist splinter the Communist Party of Australia (Marxist-Leninist).

Both the BWIU and BLF were militant unions, and under their influence the building industry had become one of the most industrially contested areas in the country. The BLF had become particularly infamous for its militancy and had often come into conflict with the BWIU, the BLF representing less skilled building workers than did the BWIU. Gallagher was also under suspicion of corruption at the time indeed in 1981 the conservative federal government had instituted proceedings to deregister the BLF from being able to appear before the Australian Conciliation and Arbitration Commission, the federal industrial relations umpire (Mitchell 1996:280304, Ross 2004).

Upon the election of a federal Australian Labor Party (ALP) government in 1983, the Australian Council of Trade Unions (ACTU) tried to achieve an agreement between the building unions and employers to reduce industrial disputation. The deregistration proceedings against the BLF were withdrawn and a new federal wagefixing process overseen by the Arbitration Commission was adopted by the incoming government. The payment negotiated as part of the building industry agreement was rejected by the Arbitration Commission as outside the new wage-fixing process, however, and the ACTU's secretary Bill Kelty subsequently persuaded Clancy and the heads of most of the smaller building unions to convert the agreed $\$ 7$ weekly payment into a claim for an employer-funded superannuation allowance (Weaven 2016, Easson 2017, Mees and Brigden 2017:47-48).

After a rival campaign for a $\$ 9$ pay rise was abandoned by the BLF, the question became what to do with the superannuation contribution. At the time, superannuation in the private sector was dominated by corporate funds managed in partnership with life insurance companies. These partnerships varied from arrangements fully managed by insurance companies through to self-administered corporate schemes. Most commonly the life insurance provider would have marketed the scheme to the company originally and offered to provide all the associated services under what was known at the time as a "deposit administration" arrangement. In the 1950s, most large employers had adopted superannuation schemes, either as group endowment policies (where members would be credited a bonus distribution from the life office each year), but increasingly from the 1960s superannuation arrangements were provided in the form of final salary or defined benefit schemes governed by a trust deed (Gray 1977:238-39).

In a survey published just after BUS had become operational, Knox (1984) describes the management of a contemporary Australian superannuation scheme as having five elements:

1. Administration: record keeping, reports to members, entry of new members, benefit payments.

2. Investment: purchase and sale of assets, analysis of current and prospective investments, investment policy

3. Legal: trust deed arrangements and amendments, implications of current and proposed legislation 
4. Actuarial: regular review of scheme's financial progress, costing advice with respect to possible changes in benefit design

5. Consulting: general or specific advice concerning trends within the superannuation industry

Smaller union-sponsored schemes established in the 1960s and 70s had tended to be self-administered, but with their investments managed by external advisors. The Stevedoring Employees Retirement Fund (sponsored by the Waterside Workers' Federation) and the Pulp \& Paper Workers Superannuation Fund (run for its members by the Pulp \& Paper Workers' Federation) had used the merchant banks Capel Court and Schroder, Darling \& Co. as their investment managers. The Labour Union Cooperative Retirement Fund (LUCRF), established by the Federated Storemen and Packers' Union, had employed Arthur Andersen as consultants when setting up their scheme, but had administered LUCRF internally -- and after initially using the stockbrokers Roach, Tilly, Grice \& Co. as investment advisers, by the 1980s had even developed their own internal investment capacity (Shaw 1992:243-47). The Storemen and Packers had loudly promoted their scheme after they established it for skin and hide workers in 1978, with the fund's chairman Storemen and Packers president Bill Landeryou agitating for a comprehensive recasting of occupational superannuation (Landeryou 1978, Olsberg 1997:77-79). LUCRF's fund secretary Harry Saint even opined publicly in 1986: "If the union movement gets off its bum and trains people properly, there is no need to hand the union superannuation funds over to the insurance companies ... What's the point of going to fight for the money, and then handing it back?" (Jack 1986). On the other hand, the BLF's Gallagher was being advised at the time that the millions of dollars generated by the building unions scheme would provide the BLF with "an avenue of influence with regards to specific building projects, with a view to the mutual benefit of the fund members and the union membership" (BLF 1984a). The ACTU had recently amalgamated with the peak unions that represented public-sector workers, many of whose affiliates had much greater experience of superannuation (Griffin and Giuca 1986). But publicsector schemes had always been administered internally and very few had ever employed external investment managers (Rowe 1984).

The prevailing view in the broader investment industry at the time seemed to be the reverse of that represented at LUCRF. In its 1979 superannuation handbook, the leading Victorian actuarial consultancy E.S. Knight \& Co. advised: "the services provided by life offices can be a great help to the employer, especially in the case of smaller funds, where the work involved does not justify the employment of a full-time secretary". E.S. Knight \& Co. had helped design the ACTU's own scheme in 1979, although the plan (which was originally hoped to cover two million members) had largely been abandoned after it had failed to attract the support of the ACTU's affiliate unions (Olsberg 1997:80). In deposit administration contracts, both administration and investment were typically "bundled" together by the life offices, along with the provision of life insurance, legal, actuarial services and consulting. The trust deeds which established the rules of corporate funds were also held to be private rather than public documents that could be scrutinized by union officials. The life insurers saw superannuation as a business to be sold to employers, their main competitors being actuarial consultancies such as E.S. Knight \& Co. and investment specialists such as Schroder, Darling \& Co. 
Knox's 1984 survey of corporate schemes bore out E.S. Knight \& Co.'s sentiment showing that the smaller the scheme, the higher the cost of administration per member. The lower the level of contributions to the scheme, the more costly it also seemed to be to administer internally (table 2). With projected numbers of members in the tens of thousands and small individual benefits, the obvious solution for the building unions was to out-source the administration of their scheme to an established superannuation provider. Unions had been able to manage smaller schemes themselves, just as they did union membership dues and other benefits traditionally afforded their members. But with hundreds of employers and tens of thousands of members, the likely size of the building unions' scheme and speed at which the unions needed to move suggested the need to contract out the administrative function to an established provider with the appropriate hardware and software computer facilities.

Clancy's successor and BWIU representative on the board of BUS was Tom McDonald and the key figure in the ACTU to work with the building unions was the former Municipal Officers' Association (MOA) secretary Garry Weaven. With the BLF latecomers to the scheme, McDonald became the most important figure in the development of BUS. As he recalls "we had a campaign in the 70s for long-service leave based on service to the industry which required central funding ... the longservice leave scheme got stuffed up because it was badly designed and we tried to do too much." Instead, McDonald and Weaven decided that the key to the success of the building unions' superannuation scheme would be simplicity.

Everything the building unions and the ACTU put into place was focused on avoiding complexity. A defined benefit arrangement (as was dominant in corporate and public-sector schemes at the time) was considered but rejected as infeasible and a simple defined contribution or accumulation arrangement along the lines used at LUCRF was preferred (ACTU 1983). The initial employer contribution to BUS was $\$ 9$ per week, plus $\$ 1$ for life insurance and $\$ 1$ for administration and reserves, making the scheme simple to sell to members. Unlike the Storemen and Packers' Union who eventually went so far as to develop their own computerized administration system, the building unions decided to let the ACTU send out tenders on their behalf for BUS's administration (Kelty 1984). The building unions and Weaven eventually decided to accept a tender from the Colonial Mutual Life Assurance Society (CML) who had recently established a separate superannuation business (Jacques Martin) and had an established administrative software platform (CML 1984). Despite the ACTU having made clear in its letter to the insurance companies that they only wanted an administration service, CML's larger rival the National Mutual Life Assurance Society still tried to bundle their administration proposal with insurance and investment services in their tender, and could only promise to develop a software platform in the future to administer BUS (NMLA 1984).

Since the 1970s, the ACTU had begun to get involved in business enterprises in order to drive down consumer prices. Knowledge gained from the experiences in the 1970s at Bourke's (a low-cost department store in Melbourne) and ACTU Solo (a cutprice petroleum retailer) were carried into the ACTU's involvement in superannuation (D'Alpuget 2010:273-86 and 439). After deciding on an administrator, the trustees of BUS next decided to offer cut-priced life insurance cover, much as the Pulp and Paper Workers' scheme had included life insurance coverage. Rather than contracting CML or one of the other life offices to provide their group insurance, however, BUS was 
large enough for the fund's trustees to deal directly with a reinsurer. The Victory Reinsurance Company of Australia won the life insurance contract for BUS at substantially reduced terms to those offered by the main life insurance providers (BUS 1984).

The union trustees of BUS had less idea what to do initially with investment. By late 1984, several employer association representatives had agreed to come onto the board, with an eventual 50/50 arrangement to develop in the following years. All the funds under management were initially awarded by the trustees to Colonial Mutual to invest in their CML Capital Guarantee Fund, but a substantial mandate was also awarded later to the largest life insurer, the Australian Mutual Provident Society (AMP). Weaven had a considerable background in superannuation from his time as secretary of the MOA. Members of the MOA were enrolled in many different publicsector schemes and Weaven had served as his union's nominated director on the Local Authorities Superannuation Board in Victoria from 1977-85 (Weaven 2016). The poor investment practices of public-sector schemes (the majority being run on a pay-as-you-go basis) contrasted sharply with the investment returns achieved by plans such as the Stevedoring Employees Retirement Fund and LUCRF that invested heavily in equities. With Weaven serving as non-voting chair of BUS, the building unions and the representatives of employer associations they invited onto the trustee board quickly developed competency in managing a range of commercial investment providers.

There was, however, a fourth major organisational capacity that the industry schemes had to arrange: coordinators to promote the schemes to union members. BUS began with one coordinator, Mike McKay, a seconded official from the Operative Painters' and Decorators' Union, who would also serve as BUS's fund secretary from late 1984 (Holt 1986:108-9). Jacques Martin developed advertising material for BUS, but in the face of resistance from many employers, demonstrated that they didn't have the capacity to sign up employers and members to the scheme in an environment of industrial conflict. Most of the funds eventually appointed coordinators in the states in which they operated and adopted similar superannuation publicity campaigns.

The coordinators were crucial to the success of funds such as BUS. Yet if anything, the push to get employers to sign up to BUS could be criticised for going too far. The coordinator often worked with local union delegates to sign up employers and members, preparing "hit lists" of employers who had not yet signed up to the schemes (Parish 1985). BUS even introduced membership cards that were used to bar non-members from being employed at building sites (Shaw 1992:258). But some unions were more active in pressing their claims with employers than others. The BLF, for example, characteristically advised its members at the time (BLF 1984b):

The Building Unions Superannuation Scheme (B.U.S.) is under direct threat from the employers. A conspiracy to undermine and torpedo our hard won 'super' has been discovered. A number of construction companies and subcontractors have embarked on activities designed to circumvent B.U.S. All building workers must now take immediate collective action to make the scheme work ... It is time for all building workers to take up the employers' challenge. We must defend and extend the Building Unions' Superannuation Scheme. The employers' stalling tactics must be defeated. 'Bodgy' employer schemes must be exposed. 
Although the approach of the BLF was typically more militant, early fund coordinators such as McKay mostly relied upon union delegates and members' meetings to promote enrolment in the industry schemes. After the campaigning had finished in the 1980s, however, the coordinators employed by the funds took up the role of membership services and marketing officers, providing specialist advice to fund members in each of the states separate from the services provided by the external fund administrators.

\section{Organizational mimesis}

With the establishment of BUS, soon other unions began to press claims for employer-paid superannuation for their members. Kelty had observed a knock-on dynamic at the time of the creation of LUCRF. The Meatworkers' Union had also been campaigning for a retirement fund at the time and "the skin and hide workers said well we want superannuation too ... we want superannuation because we don't want to be regarded as second-class citizens against the people who work at the abattoir next to us" (Kelty 2015). The Australian Workers' Union (AWU) would respond similarly in late 1984 with its New South Wales state secretary Ernie Ecob observing: "there mightn't be much concrete around the building sites. I would say the rank and file will be looking at cutting off concrete and the supply of sand and gravel because blokes working in the quarries will be looking for the same increase to commence from the same date" (Canberra Times 1984).

As Kelty foresaw, the achievement of superannuation by the building unions provided the momentum for the establishment of a national superannuation campaign. The next unions to achieve payments for their members were the construction unions that had been excluded from BUS at the behest of Gallagher. At a meeting of construction unions in Sydney in May, the Federated Engine Drivers' and Firemen's Association suggested that the construction unions could adopt their fledgling Combined Trade Union Retirement Fund, while the AWU pointed to their own superannuation scheme, established for their members by its financial services wing in 1976. Weaven indicated that events were unfolding too quickly and there was "no choice but to establish a parallel scheme to that currently being introduced by the building unions" (ACTU 1984). The construction unions' fund would be named the Allied Unions Superannuation Trust (AUST). Weaven would chair both schemes' meetings concurrently, with both BUS and AUST using Jacques Martin as an administrator and adopting identical life insurance and investment arrangements.

The next industry superannuation plan to be created after the establishment of AUST was the Transport Workers' Union's scheme, the TWU Superannuation Fund. Rather than use the ACTU's help, the Transport Workers hired the Sydney-based financial consultants AM Counsellors (now AM Corporation) to help design their scheme. Led by the union's secretary Harry Quinn, the Transport Workers' fund would be set up on the same lines as BUS and AUST, but with AM Counsellors as the administrators and more flexible arrangements made in its trust deed (Bray and Rimmer 1987:278, Bowden 1993:177-78). The Timber Workers' Union in Victoria similarly adopted the BUS model when developing their scheme in 1984, with the 
union adopting the Victorian fund in 1985 as the national Timber Industry Superannuation Scheme (Mees and Brigden 2017:60-61).

The origins of AustralianSuper can be traced to the 1985 establishment of the Metal Unions Superannuation Trust (MUST) by the Metal Trades Federation of Unions. The Amalgamated Metal Workers' Union (AMWU) had initially been opposed to union involvement in occupational superannuation, its Victorian secretary John Halfpenny observing in 1979: "there is a danger of conflict of interests when the unions go into superannuation projects ... The proper body to establish a national superannuation scheme is the government" (Harbord 1980:268). After the establishment of AUST, however, the AMWU agreed to support a national metals industry scheme, renamed in 1986 as the Manufacturing Unions Superannuation Trust (and again in 1988 to the Superannuation Trust of Australia). MUST was also chaired by Weaven and similarly adopted the BUS model in its administration, life insurance and investment management (Mees and Brigden 2017:61).

As ACTU coordinator Eamon Cuddihy recalls, a major issue he experienced in signing members up to AUST and MUST was trust: "What a lot of [members] were really worried about was who controls it. They didn't want National Mutual, they didn't want AMP. They didn't want defined benefits. Everybody knew somebody that got burnt in those schemes" (Cuddihy 2015). Defined benefit plans (which paid a pension or lump sum based on the salary the employee had at retirement) had been designed by actuaries in a manner that favoured corporate executives and were arranged so that most of the employer's contributions would be used to pay allowances to those closest to retirement rather than being equitably vested with all scheme members. With eligibility restrictions and lack of portability of benefits when they changed jobs, Greg Sword, the Storemen and Packers official who had established LUCRF, described superannuation as a "con-trick for most workers in company schemes" (Robinson et al. 1985). Much of the blame was laid by unions at the feet of the insurance companies that had designed and administered the defined benefit arrangements. The question for the trustees of the industry funds was how to harness the expertise in superannuation provision accumulated by the insurance companies, but to remain in control of the plans. The main choice made by the union officials who established the industry schemes was whether to exclude the life offices altogether from their plans (as the Storemen and Packers had decided with LUCRF) or to engage with providers such as Colonial Mutual in a differently predicated partnership arrangement to that which had applied under deposit administration.

Yet the self-administered funds were often less successful in attracting members than others. In early 1987, the Food Preservers' Union established their own Food Industry Superannuation Trust, and following the LUCRF model, hired staff so that the union could administer the scheme. But as Cuddihy recounts (Cuddihy 2015):

The Food Preservers had their own fund. We wouldn't put one member into that, because it was [just] a $\mathrm{P}[\mathrm{ost}] \mathrm{O}$ [ffice] Box in Nunawading, and we couldn't find out what it was about, who was behind it, where the money was... all we could get was a PO Box, and no telephone number. It was the same with LUCRF. It's not that there was anything wrong with those funds, it's just that nobody knew anything about them and they made it a closed secret, and that killed them. 
Meanwhile, the federal government had become increasingly interested in what the unions were achieving with occupational superannuation. Since the late 1960s, ALP policy had been to establish a national superannuation arrangement that employers and employees had to contribute to, with benefits (as in European models) funded on a pay-as-you-go basis. In September 1985, however, Kelty went to Canberra to meet with the Prime Minister Bob Hawke and his Treasurer Paul Keating to negotiate a new Prices and Incomes Accord between the ACTU and the federal Labor government. "It was a very, very tough meeting" Kelty recalls (Kelty 2015). The first Accord had been negotiated while the ALP was in opposition - indeed before Hawke had become leader of the federal parliamentary party and prior to Keating taking on the Treasury portfolio (Singleton 1990:134-54). During the first Accord negotiations, the Storemen and Packers and Kelty had managed to get superannuation mentioned as a matter for future action (Easson 2017). But this time Kelty wanted to go further. After getting the agreement of Hawke and Keating, Kelty recalls "Keating became a champion - became the champion for super" (Kelty 2015). A minimum 3\% superannuation safety net was included in the second Accord. Kelty came back from Canberra elated (Mees and Brigden 2017:63-64).

With the support of the federal government, the ACTU pushed to have a national 3\% superannuation claim ratified by the federal Arbitration Commission. After an attempt by employer organisations to halt the commission's proceedings in the High Court, in June 1986 a provision for 3\% superannuation was adopted in the federal industrial system. Superannuation would spread out across the Australian economy as an industrially predicated right that covered $80 \%$ of the workforce (Mees and Brigden 2017:66-69). Unions had to bargain and campaign for superannuation, with employers often winning productivity trade-offs in return. At Carlton \& United Breweries, for example, members lost their cherished daily beer allowance which had been causing all sorts of heath and safety concerns. As the ACTU industrial officer who led the negotiations Ian Court remembers, the beer allowances at the breweries were replaced with "refrigerated cabinets with ... light [beer] and coke and lemonade. You can imagine the workers were not particularly impressed" (Court 2015). But the main dispute was usually over which scheme the $3 \%$ payments would go into: an industry fund, a pre-existing corporate scheme, or increasingly, a rival industry superannuation plan set up as an alternative to a union-established scheme. Federal and state industrial relations tribunals were the bodies that ratified agreements over which schemes the $3 \%$ payments would be made into under the unique Australian system of industrial "awards" (Hamilton 2011).

In early 1986, Dick Wasson, the assistant national secretary of the Federated Clerks' Union (FCU), recorded in a memo that the general manager of industrial relations at brewing company Castlemaine-Tooheys had told him (Wasson 1986):

the Companies' attitudes fell into two camps. Carlton and United Breweries and the companies in that group, which are controlled by Elders I.X.L. would gladly opt for an industry-type scheme. In general, the reason was the great diversity of funds they currently operate and the diversity of industries which are interwoven in them would make the task of incorporating the 3\% in existing funds quite difficult. On the other hand Castelmaine/Tooheys consider they have a very good fund currently operating and they are anxious to preserve it. 
The FCU was a Catholic-led union, headed by the anti-Communist John Maynes. In early 1986, he and his fellow anti-Communist union leader Jim Maher had agreed to establish a single superannuation scheme for the membership of the FCU and the Maher-led Shop, Distributive and Allied Employees' Association (SDA). Like the BLF, the SDA were initially opposed to the superannuation claim and both antiCommunist unions had only recently been allowed into the ACTU. Both the FCU and the SDA had been associated with the Democratic Labor Party, formed in the 1950s during a rancorous split in the ALP, and were still widely seen as opponents to unions such as the BWIU and the BLF.

The two Catholic-led unions seemed determined to do things their own way. The joint FCU and SDA fund for clerical, administrative and retail employees would come to known as CARE Super and it was established quite separately from the other industry schemes. Maynes asked their accountant Gabriel Szondy to seek tenders from a range of sources, from AM Counsellors to Jacques Martin, the AMP Society and National Mutual (Szondy 1986). The FCU eventually decided to accept the tender of the AMP Society and similarly received approaches to manage CARE's investments from a range of investment advisors. After examining the manner in which other union-established funds operated, the FCU adopted the outsourced BUS model with minimal involvement from the ACTU, Weaven or unions other than the SDA.

The SDA's relationship with CARE, however, was interrupted in 1988. The SDA had won agreement for a superannuation claim from the Victorian Cain Labor government as part of a trade-off for agreeing to Saturday afternoon trading. As Maher recalled some years later "The package was [a] \$25 a week [pay rise], three per cent super and Saturday work to be voluntary ... I took it to Cain, and he grizzled about the $\$ 25$ but we eventually made progress" (Tennison and Niven 2009:94). But as Maher recounted, the national retail employers were opposed to the plan (Tennison and Niven 2009:94):

They wanted payments to be made into company superannuation funds where they would have complete control. They also wanted to exclude part-timers and casuals, so they mounted a challenge against the whole package in the Victorian Industrial Relations Commission.

After 40 days of hearings and 40 witnesses' testimony, the SDA won the superannuation claim, but in June 1988 the Victorian commission decided against selecting CARE as the fund into which contributions would be paid, instead favouring the employers' more recently established Retail Employees Superannuation Trust (REST). The superannuation arrangements made in Victoria would be adopted in industrial awards right across the country. Covering employees in the supermarket, retail and fast-food industries, REST would eventually overtake BUS to become the largest superannuation scheme in Australia (Mees and Brigden 2017:80-81).

Despite being established as a rival industry scheme, REST still came to adopt the BUS model, hiring National Mutual as its fund administrator. The Australian Retirement Fund, set up by the Australian Chamber of Commerce as an alternative to MUST, similarly adopted the outsourced BUS model, employing the AMP Society as its fund administrator. The BUS model was so widely accepted, even rival employerestablished schemes adopted its basic characteristics. By the end of the 1980s, the 
great majority of the industry funds, whether founded by unions or employer associations, had come to take on the same basic management structure, much to the evident disappointment of people such as LUCRF's Saint.

\section{Mimesis in a closed market}

The establishment of BUS was significantly disruptive of the pre-existing environment of retirement-savings provision and led to the foundation of an entirely new sector within the Australian finance industry. Eventually overtaken by REST and now dwarfed by AustralianSuper (the result of the 2006 merger of the Australian Retirement Fund with the Superannuation Trust of Australia), the influence of BUS has clearly been isomorphic. By establishing a "new normal" in the management of superannuation fund provision, the creation of BUS significantly contributed to the structuration (Giddens 1984) of the present-day retirement-savings and broader financial industry.

Yet the form of organisational isomorphism that developed in the industry superannuation sector is not well explained by DiMaggio and Powell's 1983 framework. There was no established profession of industry fund trustees, secretaries or coordinators to influence the manner in which the industry funds developed neither McDonald nor Weaven nor any of the other key contributors to the creation of BUS had professional backgrounds in the finance industry. It is also clear that the federal and state governments had a supportive rather than determinative role in the development of industry superannuation. The main regulatory reforms and industrial interventions undertaken by the Hawke and later Keating governments postdate the creation of BUS. In 1984, the federal industrial relations minister Ralph Willis was involved in facilitating talks between the building unions, the ACTU and the relevant employer associations. But the prospect of government coercion did not eventuate until after the signing of the second Accord in late 1985, well after the BUS model had begun being replicated by the new series of union-sponsored superannuation schemes that emerged in its wake (Mees and Brigden 2017:49).

The third dynamic of organizational isomorphism proffered in the framework of DiMaggio and Powell is mimesis. In this form of isomorphism, organizations copy the features of "similar organizations in their field that they perceive to be more legitimate or successful" (DiMaggio and Powell 1983:152). But there are several problems with seeing the replication of the BUS model in this manner. First, the industry funds do not compete against each other - there was no competitive market in superannuation provision in Australia until the conservative government introduced (limited) competition under the Legislation Amendment (Choice of Superannuation Funds) Act 2005 (Cth). There were also several models from which the industry funds established after BUS could have chosen. Many unions had established staff schemes in the 1970s under deposit administration arrangements with the life offices. Selfadministered schemes sponsored by the Waterside Workers' Federation, the Pulp and Paper Workers and the AWU had also developed in the 1960s and 70s. The Storemen and Packers had long been promoting LUCRF, but it was the much larger building unions' fund that became the dominant industry superannuation model. With the exception of a few examples such as the Food Industry Superannuation Trust, the overwhelming majority of the industry funds established after 1984 adopted the 
model developed at BUS in a process of mimetic rationalization guided by several logics.

BUS is the key institution created during the 1980s trade-union push to expand superannuation provision from under $40 \%$ of the working population to the entire Australian workforce. Most obviously developed by Tom McDonald and Garry Weaven, BUS emerged in light of several pre-existing constraints. As Weaven had argued to the construction unions in June 1984 "while it was preferable for unions to manage their own scheme, because of the size of membership potential in this case there was no choice but to use a large experienced company" (ACTU 1984). Within 18 months of its establishment, BUS had become the largest private superannuation fund in the country and a template for the establishment of other industry superannuation schemes. Over 100 similar retirement-savings plans were established by unions and employer associations in the late 1980s, with Jacques Martin the firm most commonly hired to administer the schemes. The "unbundled" model of superannuation provision established at BUS spread across the industry as the late 1980s saw the life offices come actively to seek out business with the industry funds and a range of investment consultants and managers approached their boards hoping to secure investment mandates. Most of the industry superannuation funds still outsource their administration, insurance and investment management today, following the model established at BUS in the 1980s.

The key features which explain this isomorphism, however, are not well explained by DiMaggio and Powell's emphasis on replication, state coercion and professionalization. The industry funds emerged as social enterprises that consciously disrupted the established practice of the for-profit market and had several management models available to choose from. Where companies had previously been sold schemes by insurance companies under market conditions, the industry funds were established in a coercive environment predicated on industrial disputation union campaigning and bargaining - not as a result of professional norms or state action. BUS was created using industrial power that allowed the building unions and the ACTU to overturn pre-existing arrangements. But the new management model created at BUS was developed in a manner that engaged with (rather than rejected) prevailing market practices.

The most obvious actor to have influenced the development of the industry funds was the ACTU. Before the establishment of BUS, however, the ACTU had been widely dismissed by its affiliates as a graveyard - the place union leaders went as a last resort (Briggs 2004:241). But since the 1970s experiments with Bourke's and petrol retailing, the ACTU had been involved with developing businesses that aimed to disrupt cartels and drive down retail prices. Industry superannuation is the most successful form of business developed by the Australian union movement and it was established significantly as a way of wresting power away from employers and insurance company providers. The form that the funds took was commensurate with their origin in a protracted union campaign which saw the industry sector established as a new way of providing superannuation. And two main models of union superannuation had emerged at the time in reaction to deposit administration, the older fully in-sourced arrangement typified by LUCRF or the unbundled arrangement pioneered by BUS. A more traditional style of superannuation provision seemed to be ruled out by the disdain felt in union ranks for the established for-profit providers at the time. 
Yet superannuation was a new issue for many of the ACTU's affiliates in the 1980s and the new schemes were developed in an environment of uncertainty. A new approach to superannuation had developed with the creation of BUS and most other unions, and later even employer associations, would come to adopt the outsourced BUS model. The isomorphism that occurred in industry superannuation developed in reflection of a logic of union control, the key matter that had been of concern under deposit administration. The building unions and the ACTU had established a simple, cost-cutting management model that disrupted the traditional arrangements under which corporate superannuation schemes had been established and governed, but it remained one under which the administrative and consulting expertise of the traditional superannuation providers could still be harnessed. Upon the establishment in 1984 of the first of the new breed of union-sponsored superannuation funds, the logic of serving and selling that had dominated private-sector superannuation previously was replaced by a new model based on a logic of simplicity, cost-cutting and control.

\section{Conclusion}

By 1984 several different models of superannuation provision had emerged. The deposit administration arrangement sold by life insurance companies in the private sector was dominant, but was rejected by the building unions and the ACTU chiefly on the grounds of a logic of control. It was the simplicity and prominence of the BUS scheme, however, that seemed most attractive to later union and employer association officials when they came to set up their own superannuation schemes. Rather than adopting the stand-alone model of LUCRF developed in a complete rejection of the tradition of deposit administration, the BUS model allowed trustees to enlist the administrative support and technical competence of life insurance firms and specialist investment managers. The BUS model quickly became dominant in industry superannuation as it was judged a superior manner in which to design and manage a scheme by the trustees who formed similar wealth management companies in the later years of the 1980s, whether they came from a union or even a rival employer association background.

After the BUS model became dominant, it also remained in place as the logics of simplicity, cost-cutting and control produced organizational isomorphism throughout the industry sector. The largest industry funds have retained the BUS model as they developed and grew to the position where they now dominate the broader superannuation market. Cbus, REST, AustralianSuper and the other leading industry funds still outsource their administration, life insurance and investment management on the grounds first established in the 1980s. REST and more recently AustralianSuper have since developed limited internal investment management capacities, but the key managerial distinction between an industry fund and an old public-sector scheme (or even one run by a for-profit provider) remains their commitment to outsourced administration. Most of the staff who work directly for the industry funds have coordination roles, much expanded as they may have become in what since the 1980s have developed into the largest private not-for-profit Australian wealth management providers. 
Above all, however, the development of organizational isomorphism in industry superannuation brings out a key limitation of the tripartite framework established by DiMaggio and Powell. So ambitiously and loosely based, their explanation of the emergence of organizational mimesis has required theoretical expansion to explain the scheme designs and management models developed by a successful group of alternatively governed finance organizations. The classic tripartite framework of DiMaggio and Powell fails to consider how the introduction of new logics and forms (and sources) of coercion may inform the emergence of new business models. Management scholarship and the sociology of organizations needs to embrace a broader understanding of organization if it is to make more generalizable claims than those that apply in analyses of more traditionally governed organizations.

\section{Acknowledgements}

The interviews and archival research employed in this paper were undertaken as part of the Workers' Capital project at RMIT, funded by the Australian Institute of Superannuation Trustees, supported by Industry Super Holdings. Some of the interviews were undertaken by or with Cathy Brigden and Aron Paul, the archival research by Aron Paul and Eleanor Bentham.

\section{References}

\section{Interviews}

Ian Court, 18 November 2015.

Eamon Cuddihy, 6 July 2015.

Bill Kelty, 16 December 2015.

Tom McDonald, 16 March 2015.

\section{Unpublished sources}

ACTU (1983), ACTU/union proposal for a national superannuation scheme for the building industry, 21 December 1983, Super campaign, N 129/1975, Noel Butlin Archives Centre, Canberra.

ACTU (1984), Minutes of meeting on superannuation in the building and construction industry, 13 June 1984, B.U.S. scheme, N 130/1052, Noel Butlin Archives Centre, Canberra.

BLF (1984a), Memo: Harrison to the General Secretary, 23 March 1984, B.U.S. Scheme, N 130/1052, Noel Butlin Archives Centre, Canberra.

BLF (1984b), "Defend and Extend Building Unions Super", 18 September 1984, B.U.S. Superannuation, N 129/310, Noel Butlin Archives Centre, Canberra.

BUS (1984), Minutes of the meeting of the board of directors of B.U.S. Pty Ltd, 29 May 1984, B.U.S. Scheme, N 130/1052, Noel Butlin Archive Centre, Canberra.

CML (1984), Colonial Mutual, tender for the administration of the Building Unions Superannuation Scheme, April 1984, B.U.S. Scheme, N 130/1051, Noel Butlin Archives Centre, Canberra. 
Kelty, W.J. (1984), Letter to insurance companies, March 5 1984, B.U.S. Scheme, N 130/1051, Noel Butlin Archives Centre, Canberra.

NMLA (1984), National Mutual, submission to the trustees of the Building Unions Superannuation Scheme (BUSS), April 1984, B.U.S. Scheme, N 130/1051, Noel Butlin Archives Centre, Canberra.

Parish, N. (1985), Letter to the secretaries of all the A.U.S.T. Unions, 22 May 1985, A.U.S.T. Membership 1985, N 129/38, Noel Butlin Archives Centre, Canberra.

Szondy, G. (1986), Letter seeking tenders, 25 March 1986, John Maynes papers, Box 200, State Library of Victoria, Melbourne.

Wasson, R. (1986), Notes of "off-the-record" conversation with Alan Reid, General Manager Industrial Relations, Castlemaine-Tooheys (Bond Corporation), 28 January 1986, John Maynes papers, Box 200, State Library of Victoria, Melbourne.

\section{Other references}

Birchall, J. (2011), People-Centred Businesses: Co-operatives, Mutuals and the Idea of Membership, Palgrave Macmillan, Houndmills.

Bowden, B. (1993), Driving Force: The History of the Transport Workers' Union of Australia, 1883-1992, Allen \& Unwin, Sydney.

Bray, M., and Rimmer, M. (1987), Delivering the Goods: A History of the NSW Transport Workers Union, 1888-1986, Allen \& Unwin, Sydney.

Briggs, Chris (2004), "The end of a cycle? The Australian Council of Trade Unions in historical perspective", in Ellem, B., Markey, R. and Shields, J. (eds), Peak Unions in Australia: Origins, Purpose, Power, Agency, Federation Press, Leichardt, NSW, pp. 236-60.

Canberra Times (1984), "AWU wants part of building super scheme", Canberra Times, 30 June, p. 1.

Carmichael, A. (1913), "Superannuation", Sydney Morning Herald, 13 September, p. 9.

Chandler, F. (1910), Amalgamated Society of Carpenters \& Joiners: History of the Society, 1860-1910, Co-operative Printing Society, Manchester.

Clark, R.L., Craig, L.A. and Wilson, J.A. (2003), A History of Public Sector Pensions in the United States, University of Pennsylvania Press, Philadelphia.

D'Alpuget, B. (2010), Hawke: The Early Years, 2nd edn, Melbourne University Publishing, Melbourne.

DiMaggio, P.J., and Powell, W.W. (1983), "The iron cage revisited: Institutional isomorphism and collective rationality in organizational fields", American Sociological Review, Vol. 48, pp. 147-60.

Easson, M. (2017), Keating's and Kelty's Super Legacy, Connell Court, Brisbane.

Friedland, R., and Alford, R.R. (1991), "Bringing society back in: Symbols, practices, and institutional contradictions", in Powell, W.W. and DiMaggio, P.J. (Eds), The New Institutionalism in Organizational Analysis, University of Chicago Press, Chicago, pp. 232-66.

Giddens, A. (1984), The Constitution of Society: An Outline of the Theory of Structuration, Polity Press, Cambridge.

Gray, A.C. (1977), Life Insurance in Australia: An Historical and Descriptive Account, McCarron Bird, Melbourne. 
Griffin, G. and Giuca, V. (1986), 'One union peak council: the merger of ACSPA and CAGEO with the ACTU', Journal of Industrial Relations, Vol. 28, No. 4, pp. 483503

Gunasekera, M., and Powlay, J. (1987), Occupational Superannuation Arrangements in Australia, Social Security Review Background/Discussion Paper no. 21, Department of Social Security, Canberra.

Hamilton, R.S. (2011), Waltzing Matilda and the Sunshine Harvester Factory: The Early History of the Arbitration Court, the Australian Minimum Wage, Working Hours and Paid Leave, Fair Work Australia, Melbourne.

Hannah, L. (1986), Inventing Retirement: The Development of Occupational Pensions in Britain, Cambridge University Press, Canberra.

Harbord, G. (1980), “Superannuation: privilege or benefit?", Australian Bulletin of Labour, Vol. 6, pp. 264-65.

Hartmann, R.K. (2014), 'Subversive functionalism: For a less canonical critique in critical management studies'. Human Relations, Vol. 67, No. 5, pp. 611-32.

Holt, P., Ed. (1996), An Oral History of C+BUS: The Construction and Building Industry's Superannuation Fund, National Centre for Australian Studies, Monash University, Melbourne.

Howard, J. (1985), House of Representatives Hansard, 25 November 1985.

Jack, P.D. (1986), "Who's afraid of the share market", Australian Business, October 22, p. 86

Jones, H.R. (1917), The Miners' Next Move: A Plea for the Abolition of the Contract System in Coal Mines, The Worker Trade Union Print, Sydney.

Knight, E.S. \& Co. (1979), Superannuation Planning in Australia, 2nd edn, CCH, North Ryde, NSW.

Knox, D. (1984), "Economies of scale in the management of occupational superannuation schemes", Journal of the Institute of Actuaries, Vol. 111, No. 2 (September), pp. 337-61,

Landeryou, W.A. (1978), "The union attitude to superannuation", Superfunds, December, pp. 30-31.

Latimer, M.W. (1932), Industrial Pension Systems in the United States and Canada. 2 vols, Industrial Relations Counselors, New York.

Lounsbury, M. (2007), "A tale of two cities: Competing logics and practice variation in the professionalizing of mutual funds", Academy of Management Journal, Vol. 50, pp. 289-307.

Markey, R., Rafferty, M., Thornwaite, L., Wright, S. and Angus, C. (2014), The Success of Representative Governance on Superannuation Boards, Centre for Workplace Futures, Macquarie University, Sydney.

Mees, B., and Brigden, C. (2017), Workers' Capital: Industry Funds and the Fight for Universal Superannuation in Australia, Allen \& Unwin, Sydney.

Mills, C.W. (1959), The Sociological Imagination, Penguin, Harmondsworth.

Mitchell, G. (1996), On Strong Foundations: The BWIU and Industrial Relations in the Australian Construction Industry 1942-1992, Harcourt Brace, Sydney.

Olsberg, D. (1997), Ageing and Money: Australia's Retirement Revolution, Allen \& Unwin, Sydney.

Productivity Commission (2016), How to Asses the Competitiveness and Efficiency of the Superannuation System, Productivity Commission, Canberra. 
Ross, E. (1970), A History of the Miners' Federation of Australia, Australasian Coal and Shale Employees' Federation, Sydney.

Ross, Liz (2004), Dare to Struggle, Dare to Win: Builders Labourers Fight Deregistration 1981-1994, Vulgar Press, Carlton North, Vic.

Rowe, B., Chair (1984), A Review of Superannuation in the Victorian Public Sector, Government Printer, Melbourne.

Scott, W. R. (1995), Institutions and Organizations: Ideas and Interests, Sage, London.

Shaw, D. (1992), "Trade Union Participation in Public Policy: The Rise and Demise of Australia's National Retirement Income Regime", PhD dissertation, University of NSW.

Shields, R.A. (1913), "Superannuation”, Sydney Morning Herald, 17 September, p. 11.

Simon, B. (1985), "The superannuation debate in the national capital", The Australian Accountant, Vol. 55 (December), pp. 37-38.

Singleton, G. (1990), The Accord and the Australian Labour Movement, Melbourne University Press, Melbourne.

SMH (1895), "Civil Service Superannuation Fund", Sydney Morning Herald, 26 October, p. 11.

SMH (1897), "The superannuation fund", Sydney Morning Herald, 21 January, p. 4.

Robinson, P., Donahue, B. and Legge, K. (1985), "Both sides jittery on super", The Age, 13 December, p. 16.

Tennison, J., and Niven, B. (2009), Making History: SDA Victorian Branch 19082008, Shop, Distributive \& Allied Employees' Association, Victorian Branch, Melbourne.

Thornton, P., and Ocasio, W. (1999), 'Institutional logics and the historical contingency of power in organizations: Executive succession in the higher education publishing industry, 1958-1990', American Journal of Sociology, Vol. 105, No. 3, pp. 801-843.

Thornton, P.H., Ocasio, W., and Lounsbury, M. (2012), The Institutional Logics Perspective: A New Approach to Culture, Structure and Process, Oxford University Press, Oxford.

Weaven, G. (2016), “Workers' Capital: The Story of Industry Funds and Australia's Superannuation Revolution", Foenander Lecture, Melbourne University, November 16 ; available at: http://fbe.unimelb.edu.au/_data/assets/pdf_file/0017/2170313/Foenander-SpeechFinal-2016.pdf (viewed 5 December, 2017). 
Table 1. Theory of Isomorphism: Sources of Organizational Rationalization

\begin{tabular}{|c|c|c|c|}
\hline Source of legitimacy & Profession & State & Market \\
\hline $\begin{array}{l}\text { Forms of institutional } \\
\text { isomorphism }\end{array}$ & Normative & Coercive & Mimetic \\
\hline $\begin{array}{l}\text { Mechanisms of } \\
\text { structuration of } \\
\text { fields }\end{array}$ & Professionalization & $\begin{array}{l}\text { Political power, } \\
\quad \text { cultural } \\
\text { expectations }\end{array}$ & $\begin{array}{l}\text { Standard responses } \\
\text { to uncertainty }\end{array}$ \\
\hline \multicolumn{4}{|l|}{$\begin{array}{l}\text { Increase in interaction } \\
\text { of organizations }\end{array}$} \\
\hline Patterns of domination & $\begin{array}{l}\text { Status competition, } \\
\text { professional filtering, } \\
\text { assigned by state }\end{array}$ & & \\
\hline Patterns of coalition & & $\begin{array}{l}\text { Collusion, } \\
\text { government } \\
\text { mandate, budget } \\
\text { cycles }\end{array}$ & \\
\hline \multicolumn{4}{|l|}{$\begin{array}{l}\text { Increase in information } \\
\text { overload }\end{array}$} \\
\hline $\begin{array}{l}\text { Mutual awareness of } \\
\text { common enterprise }\end{array}$ & $\begin{array}{l}\text { Socialization by } \\
\text { professional, trade } \\
\text { assn. consultants }\end{array}$ & & $\begin{array}{l}\text { Practices of } \\
\text { successful } \\
\text { organizations }\end{array}$ \\
\hline
\end{tabular}

Table 2. Cost of Superannuation Fund Administration according to Knox (1984)

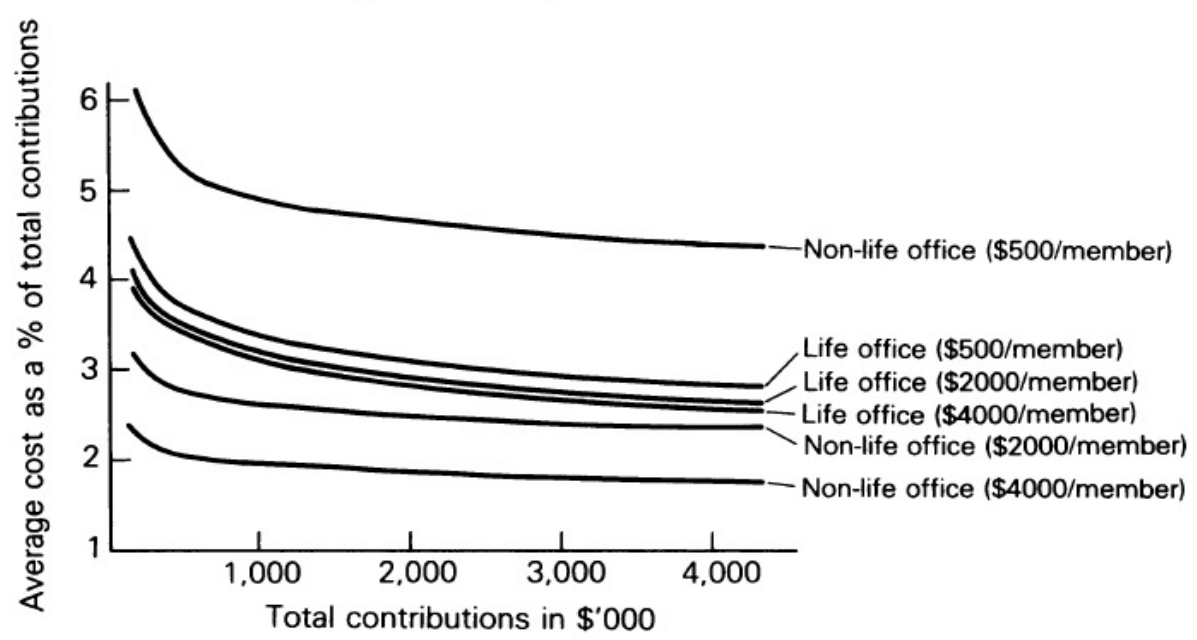


Table 3. The First Industry Superannuation Funds

\begin{tabular}{|c|c|c|c|c|}
\hline Fund & $\begin{array}{l}\text { Date } \\
\text { established }\end{array}$ & Union sponsor & $\begin{array}{l}\text { Original } \\
\text { administrator }\end{array}$ & $\begin{array}{l}\text { Successor fund } \\
\text { today }\end{array}$ \\
\hline $\begin{array}{l}\text { Allied Unions } \\
\text { Superannuation Trust }\end{array}$ & 1984 & construction unions & $\begin{array}{l}\text { Jacques } \\
\text { Martin }\end{array}$ & Cbus \\
\hline $\begin{array}{l}\text { Australian Retirement } \\
\text { Fund }\end{array}$ & 1986 & $\mathrm{ACTU}$ & AMP & AustralianSuper \\
\hline $\begin{array}{l}\text { Building Unions } \\
\text { Superannuation }\end{array}$ & 1984 & building unions & $\begin{array}{l}\text { Jacques } \\
\text { Martin }\end{array}$ & Cbus \\
\hline $\begin{array}{l}\text { Clerical, Administrative } \\
\text { and Retail Employees } \\
\text { Superannuation Fund }\end{array}$ & 1986 & FCU, SDA & AMP & CARE Super \\
\hline $\begin{array}{l}\text { Coal Mine Workers } \\
\text { Pensions Fund (NSW) }\end{array}$ & 1941 & $\begin{array}{l}\text { Combined Mining } \\
\text { Unions }\end{array}$ & $\begin{array}{l}\text { Self- } \\
\text { administered }\end{array}$ & $\begin{array}{l}\text { Mine Wealth + } \\
\text { Wellbeing }\end{array}$ \\
\hline $\begin{array}{l}\text { Combined Trade Union } \\
\text { Retirement Fund }\end{array}$ & 1983 & $\begin{array}{l}\text { Federated Engine } \\
\text { Drivers' and } \\
\text { Firemen's } \\
\text { Association }\end{array}$ & $\begin{array}{l}\text { Howarth and } \\
\text { Howarth }\end{array}$ & Cbus \\
\hline $\begin{array}{l}\text { Food Industry } \\
\text { Superannuation Trust }\end{array}$ & 1987 & $\begin{array}{l}\text { Food Preservers' } \\
\text { Union }\end{array}$ & $\begin{array}{l}\text { Self- } \\
\text { administered }\end{array}$ & AustralianSuper \\
\hline $\begin{array}{l}\text { Labour Union Co- } \\
\text { operative Retirement } \\
\text { Fund }\end{array}$ & 1978 & $\begin{array}{l}\text { Federated Storemen } \\
\text { and Packers' Union }\end{array}$ & $\begin{array}{l}\text { Self- } \\
\text { administered }\end{array}$ & LUCRF Super \\
\hline $\begin{array}{l}\text { Metal Unions } \\
\text { Superannuation Trust }\end{array}$ & 1985 & $\begin{array}{l}\text { Metal Trades } \\
\text { Federation of Unions }\end{array}$ & $\begin{array}{l}\text { Jacques } \\
\text { Martin }\end{array}$ & AustralianSuper \\
\hline $\begin{array}{l}\text { Pulp and Paper Workers } \\
\text { Superannuation Fund }\end{array}$ & 1974 & $\begin{array}{l}\text { Pulp and Paper } \\
\text { Workers' Federation }\end{array}$ & $\begin{array}{l}\text { Self- } \\
\text { administered }\end{array}$ & First Super \\
\hline $\begin{array}{l}\text { Retail Employees } \\
\text { Superannuation Trust }\end{array}$ & 1987 & SDA & $\begin{array}{l}\text { National } \\
\text { Mutual }\end{array}$ & REST Super \\
\hline $\begin{array}{l}\text { Stevedoring Employees } \\
\text { Retirement Fund }\end{array}$ & 1967 & $\begin{array}{l}\text { Waterside Workers' } \\
\text { Federation }\end{array}$ & $\begin{array}{l}\text { Self- } \\
\text { administered }\end{array}$ & Maritime Super \\
\hline $\begin{array}{l}\text { Timber Industry } \\
\text { Superannuation Scheme }\end{array}$ & 1985 & $\begin{array}{l}\text { Australian Timber } \\
\text { Workers' Union }\end{array}$ & $\begin{array}{l}\text { Jacques } \\
\text { Martin }\end{array}$ & First Super \\
\hline $\begin{array}{l}\text { TWU Superannuation } \\
\text { Fund }\end{array}$ & 1984 & $\begin{array}{l}\text { Transport Workers' } \\
\text { Union }\end{array}$ & $\begin{array}{l}\text { AM } \\
\text { Counsellors }\end{array}$ & TWU Super \\
\hline
\end{tabular}

